\title{
Mechanical and electrical properties of artificially aged aluminium alloy AA 2024
}

\author{
I. Gunes ${ }^{1}$, M. Erdogan ${ }^{2}$, B. Çengelci ${ }^{3 *}$ \\ ${ }^{1}$ Department of Metallurgical and Materials Engineering, Afyon Kocatepe University, 03200 Afyonkarahisar, Turkey \\ ${ }^{2}$ Department of Automotive Engineering, Afyon Kocatepe University, 03200 Afyonkarahisar, Turkey \\ ${ }^{3}$ Department of Mechatronic Engineering, Faculty of Technology, Afyon Kocatepe University, \\ 03200 Afyonkarahisar, Turkey
}

Received 2 December 2014, received in revised form 25 November 2015, accepted 8 December 2015

\begin{abstract}
This study investigated the $\mathrm{GP}(\mathrm{Cu}, \mathrm{Mg})$ regions formed following the artificial ageing of aluminium alloy and the effect of the $\mathrm{Al}_{2} \mathrm{CuMg}$ phases on the mechanical and electrical properties. First, AA 2024 aluminium alloy samples were maintained in a conventional furnace at $530^{\circ} \mathrm{C}$ for $20 \mathrm{~min}$ and then subjected to quenching in order to homogenise their microstructures. Then, the samples were subjected to the artificial ageing method for various periods of time in an annealing furnace at $190^{\circ} \mathrm{C}$. Following the artificial ageing of the samples, their internal structure characterisation, microhardness, mechanical and electrical properties (dielectric) were investigated. Experimental results are discussed compared to literature data.
\end{abstract}

Key words: AA 2024, aluminium alloy, heat treatment, mechanical properties, electrical conductivity, microhardness

\section{Introduction}

Due to their low density and high mechanical properties, the use of aluminium alloys is increasing rapidly in many important areas of production such as the automotive, aerospace and defence industries [1]. Despite good physical and mechanical properties, their corrosion resistance remains relatively poor [2].

Aluminium alloys on which heat treatment can be applied consist of three main groups: 2XXX, 6XXX and $7 \mathrm{XXX}$ series. The $2 \mathrm{XXX}$ series alloys are used in areas such as the aircraft industry, which requires high bulk density resistance. These alloys gain strength through solid solution strengthening and precipitation hardening $[3,4]$.

Artificial ageing generally occurs if precipitation heat treatment is conducted at a high temperature. The temperatures employed for this process depend on the alloy and the desired properties, and the temperature varies between $120-190^{\circ} \mathrm{C}$. In the first stage of the ageing process, vacancies are formed with the separation of the $\mathrm{Cu}$ atoms as solid solutions from the supersaturated matrix. Clusters of $\mathrm{Cu}$ atoms, formed in the first study that lasted one day, are referred to as GP zones [5], named after the researchers who first examined this subject in 1938: Guinier from France and Preston from Britain. In the literature, there is much speculation about the structure of these zones. GPB zones were determined by Lambot [6] and Bagaryatsky [7]. The famous $\mathrm{Al}_{2} \mathrm{CuMg}$ structure referred to as the $\mathrm{S}$ phase was determined by Perlitz and Westgenand [8], and Bischler [9]. During ageing, the $\mathrm{S}$ phase is nucleated homogeneously and grows to be a precipitate, which is fully compatible with a structure of $\mathrm{Si}_{2}$. The growth of the precipitate is related to the diffusion coefficient. The diffusion coefficient needs to be determined in this area. Anand [10] and Murphy [11] determined the diffusion coefficient of copper in pure aluminium. The appropriate information regarding the morphological changes during the ageing of Al-rich Al-Cu-Mg alloys was summarised by Hardy [12].

The importance of studies on the electrical conductivity of the alloys has increased recently. The effects of high current and high voltage on aluminium alloys used in the production of electrical equipment

*Corresponding author: tel.: +90272 22814 47; fax: +90272 22814 49; e-mail address: bcengelci@aku.edu.tr 
and high voltage power transmission lines have always been a subject of research. In addition to experimental studies, intelligent methods have been used in the estimation of conductivity [13-15].

Electrical conductivity is inversely proportional to resistance:

$$
G=1 / R=l / V
$$

where $V$ is voltage.

The equation for $A, l$ and $\sigma$ referring to an area of a conductor, length and self-conductivity, respectively, is:

$$
G=(\sigma A) / l
$$

The self-conductivity is inversely proportional to the resistivity of a conductor:

$$
\sigma=1 / \rho
$$

Conductivity is a magnitude that does not have a reactive component while admittance is the general state of this magnitude. The equation for $Y, B$ and $j$, referring to admittance, susceptance and virtual operator, respectively, is:

$$
Y=G+j B \text { or } G=\operatorname{Re}(Y) .
$$

The dependence between the electrical resistivity and the temperature, $\rho(T)$, is:

$$
\rho(T)=\rho_{0}+\rho_{0} \alpha\left(T-T_{0}\right),
$$

where $\alpha$ is temperature coefficient of resistance, $T_{0}$ is initial temperature and $\rho_{0}$ is resistor of initial value.

In several experimental methods, the electrical conductivity analysis of aluminium compounds was performed by adding different amounts of copper [16]. Moreover, studies on the thermal electrical conductivity of metals and metal alloys have been conducted due to the fact that they have an important place in industry $[17,18]$. The subject of ageing, which is another issue affecting the conductivity of the alloy, has been the focus of studies, and its effect on electrical conductivity has also been investigated [19-22].

\section{Experimental method}

The machinability, fatigue resistance and specific electrical conductivity of aluminium are higher than those of silver, copper and gold; therefore, it is suitable for the production of machines. There has been an increasing trend in the use of aluminium alloys in application areas, as well as in the electrical field, compared to traditional rival materials. The aluminium
Table 1 . The chemical composition values of aluminium alloy AA 2024 (wt.\%)

\begin{tabular}{ccccccc}
\hline $\mathrm{Fe}$ & $\mathrm{Si}$ & $\mathrm{Cr}$ & $\mathrm{Mn}$ & $\mathrm{Mg}$ & $\mathrm{Cu}$ & $\mathrm{Al}$ \\
\hline 0.5 & 0.5 & 0.1 & $0.3-0.9$ & $1.2-1.8$ & $3.8-4.9$ & Balance \\
\hline
\end{tabular}

Table 2. Duration of the artificial ageing applied to aluminium alloy AA 2024

\begin{tabular}{cc}
\hline Ageing temperature $\left({ }^{\circ} \mathrm{C}\right)$ & Ageing time $(\mathrm{h})$ \\
\hline 190 & 1 \\
190 & 3 \\
190 & 5 \\
\hline
\end{tabular}

alloy AA 2024 used in the current experimental studies was produced by the method of hot rolling. The chemical composition of the material is given in Table 1 .

In the experimental studies, the dimensions of the specimens produced for dielectric measurement analysis were $15 \mathrm{~mm}$ in diameter, and $3 \mathrm{~mm}$ in height. The test specimens were kept in a conventional furnace in an air atmosphere (Protherm PLF $120 / 12$ ) at $530^{\circ} \mathrm{C}$ for $20 \mathrm{~min}$ and quenched. Table 2 illustrates the artificial ageing process applied to the specimens in the conventional furnace atmosphere following the heat treatment.

After aluminium alloys AA 2014 were subjected to quenching, they were heat treated. Images were taken with an Olympus BX-60 optical microscope, and microhardness (Shimadzu HMV-2L) analysis, tensile test (Shimadzu-AG/IS), dielectric measurement (Linseis brand) analysis and XRD (Shimadzu XRD 6000) analysis of the untreated samples were conducted. Dielectric measurement curves were obtained from the heat-treated samples at room temperature $\left(25^{\circ} \mathrm{C}\right)$ and from the crude samples between 25 and $300^{\circ} \mathrm{C}$.

\section{Experimental results}

\subsection{Optical microscope analysis}

Optical microscope images of the crude samples quenched (at $530^{\circ} \mathrm{C}$ ) and artificially aged samples of aluminium alloy AA 2024 are in Figs. 1-5. In Fig. 1, $\mathrm{GP}(\mathrm{Cu}, \mathrm{Mg})$ zones, the scarcity of $\mathrm{Al}_{2} \mathrm{CuMg}$ phases and a heterogeneous image stand out in the optical microscope images of the untreated, crude aluminium alloy AA 2024 GP, are presented. In addition, small particles are observed in the sample as seg- 

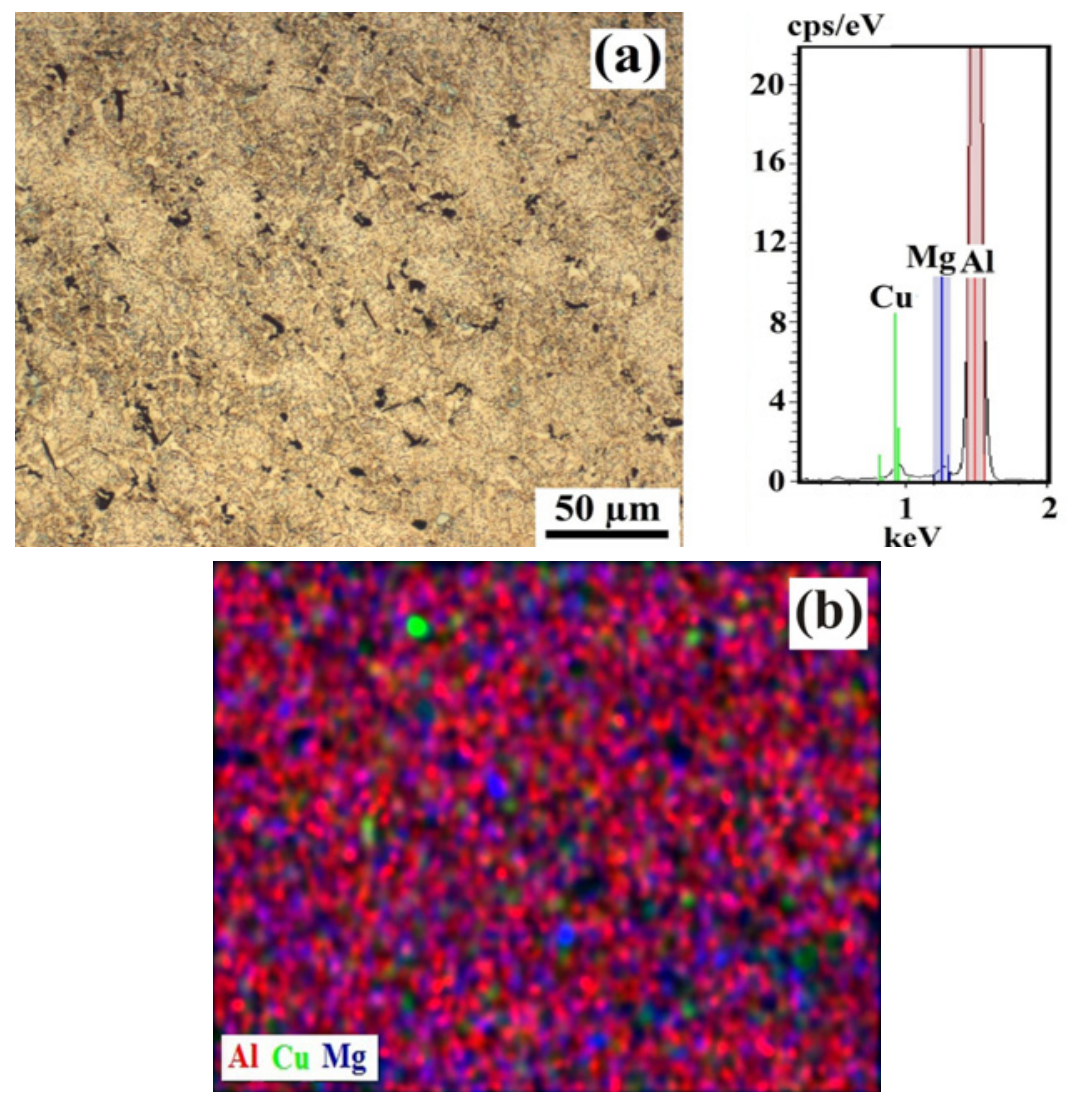

Fig. 1. Optical images of the crude sample of aluminium alloy AA 2024: a) microstructure, b) EDS analysis.
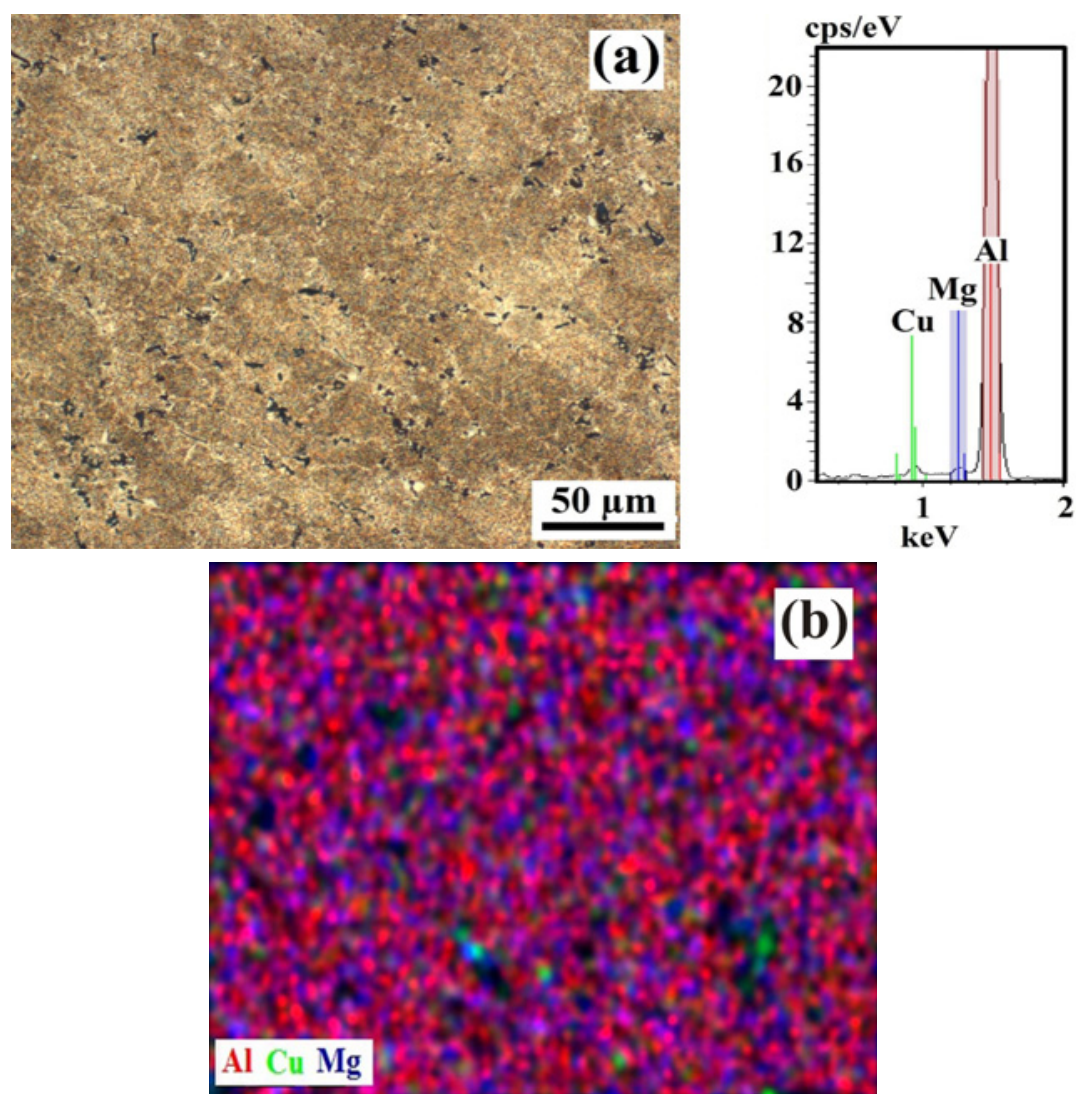

Fig. 2. Optical images of the sample of aluminium alloy AA 2024 quenched at $530^{\circ} \mathrm{C}$ : a) microstructure, b) EDS analysis. 

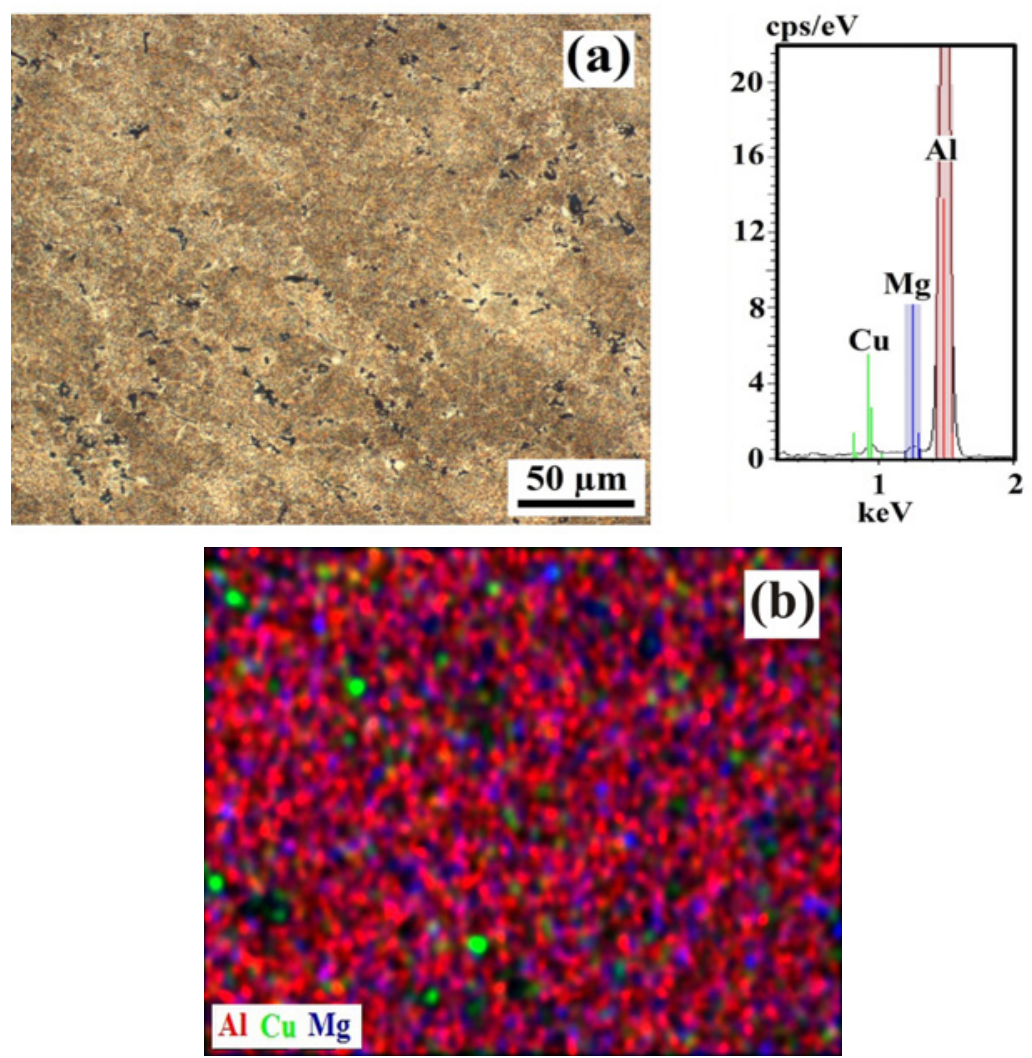

Fig. 3. Optical images of the sample of aluminium alloy AA 2024 artificially aged at $190{ }^{\circ} \mathrm{C}$ for 1 h: a) microstructure, b) EDS analysis.
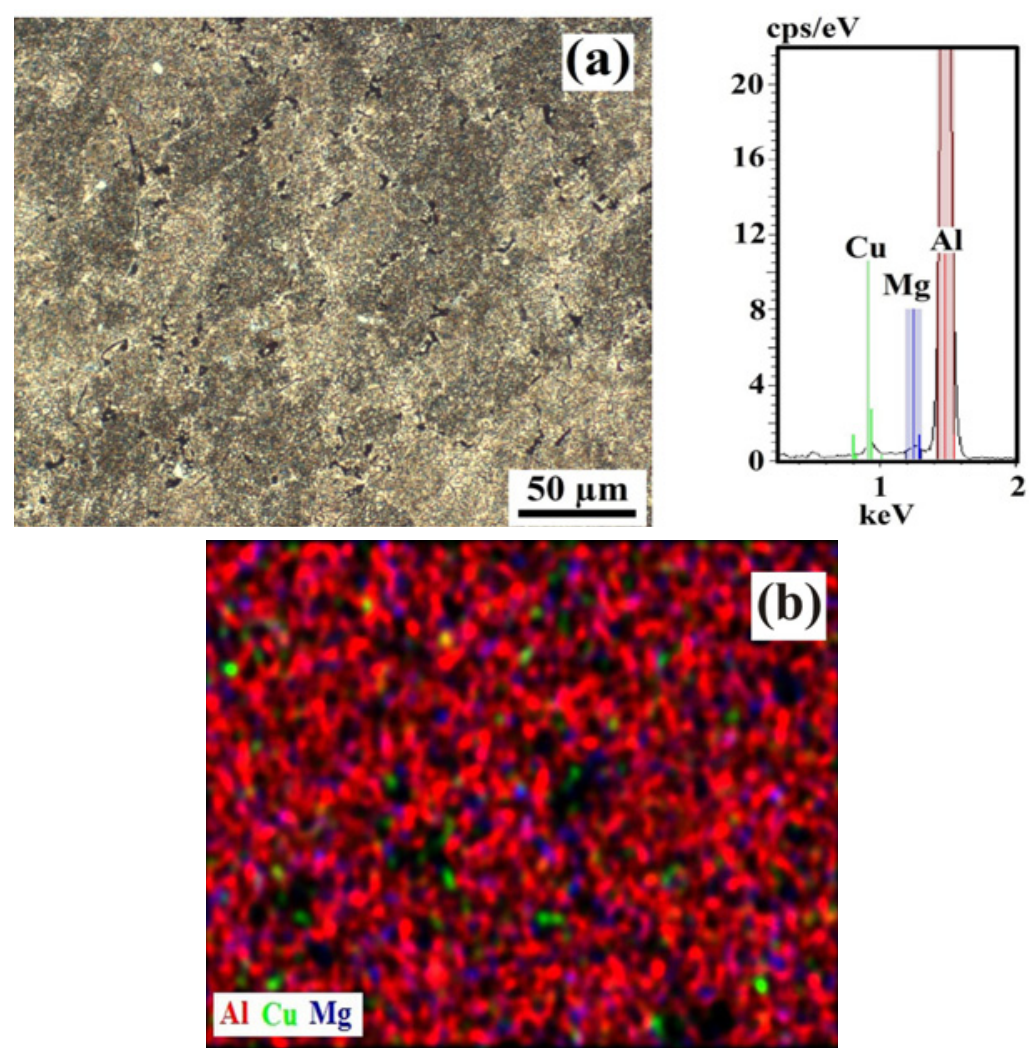

Fig. 4. Optical images of the sample of aluminium alloy AA 2024 artificially aged at $190^{\circ} \mathrm{C}$ for 3 h: a) microstructure, b) EDS analysis. 

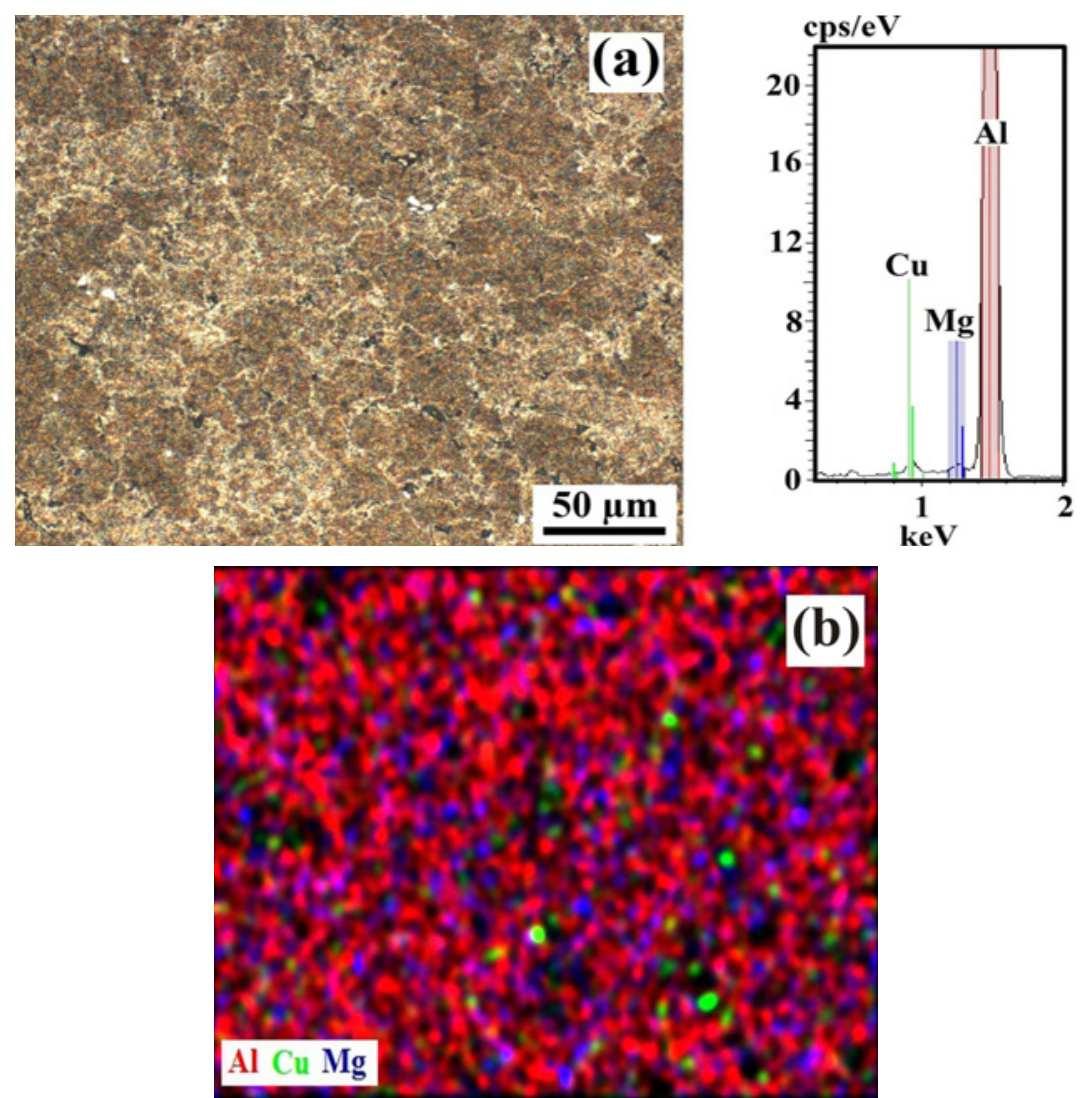

Fig. 5. Optical images of the sample of aluminium alloy AA 2024 artificially aged at $190^{\circ} \mathrm{C}$ for 5 h: a) microstructure, b) EDS analysis.

regation. Hence, $\mathrm{GP}(\mathrm{Cu}, \mathrm{Mg})$ zones, $\mathrm{Al}_{2} \mathrm{CuMg}$ phases and small particles in the samples formed a heterogeneous structure (Fig. 1). However, it was observed in the optical microscope image (Fig. 2) of the sample quenched at $530^{\circ} \mathrm{C}$ for 20 min that $\mathrm{GP}(\mathrm{Cu}, \mathrm{Mg})$ zones and $\mathrm{Al}_{2} \mathrm{CuMg}$ phases formed after the heat treatment increased and the small particles formed a homogeneous internal structure. It was also observed in Figs. 3-5 that $\mathrm{GP}(\mathrm{Cu}, \mathrm{Mg})$ zones and $\mathrm{Al}_{2} \mathrm{CuMg}$ phases formed in the internal structure of the samples that were artificially aged in the conventional furnace at $190^{\circ} \mathrm{C}$, increased in the state of thermodynamic equilibrium and the small particles formed a homogeneous structure. In the crude aluminium alloy system, particles present in the sample constituted a coarsegrain internal structure profile (Fig. 1). Test specimens showed a homogeneous internal structure with the contraction of $\mathrm{GP}(\mathrm{Cu}, \mathrm{Mg})$ zones and $\mathrm{Al}_{2} \mathrm{CuMg}$ phases observed in the internal structure, as the artificial ageing times increased during the heat treatment (Figs. 2-5). EDS curves of the crude sample of aluminium alloy AA 2024, samples quenched at $530^{\circ} \mathrm{C}$, and the artificially aged samples can be seen in Figs. 1-5. In the EDS image of the crude sample, the rates of $\mathrm{Cu}$ and $\mathrm{Mg}$ elements are lower. However, the $\mathrm{Al}$ that constitutes the internal structure of the crude sample formed a high peak value, as can be seen in the EDS analysis (Fig. 1). In the EDS curves, the peak intensity of the Al element of the artificially aged samples was observed to decrease (Figs. 2-5). It can be stated that the formation of $\mathrm{GP}(\mathrm{Cu}, \mathrm{Mg})$ zones and $\mathrm{Al}_{2} \mathrm{CuMg}$ phases present in the test specimens occurred as a result of artificial ageing. These phases that occurred in the internal structure were observed to increase the microhardness values (Fig. 6) while they decreased the tensile test analysis results (Fig. 7) and percentual elongation rates (Fig. 8).

\subsection{Microhardness analysis}

Figure 6 shows the microhardness $\left(\mathrm{HV}_{0.05}\right)$ graphs of the samples of aluminium alloy AA 2024 artificially aged at $190{ }^{\circ} \mathrm{C}$ for different periods of time, in a conventional furnace environment. The microhardness value of the crude sample was about $110 \mathrm{HV}_{0.05}$. Due to the increase in $\mathrm{GP}(\mathrm{Cu}, \mathrm{Mg})$ zones in the amount of $\mathrm{Al}_{2} \mathrm{CuMg}$ phases, and the homogeneous distribution of the particles in the sample that was artificially aged at $190^{\circ} \mathrm{C}$, the microhardness value was about 170 $\mathrm{HV}_{0.05}$ while the microhardness value of the sample artificially aged for $5 \mathrm{~h}$ was about $180 \mathrm{HV}_{0.05}$. These microhardness values measured concurrently are the maximum microhardness values measured in the system. 


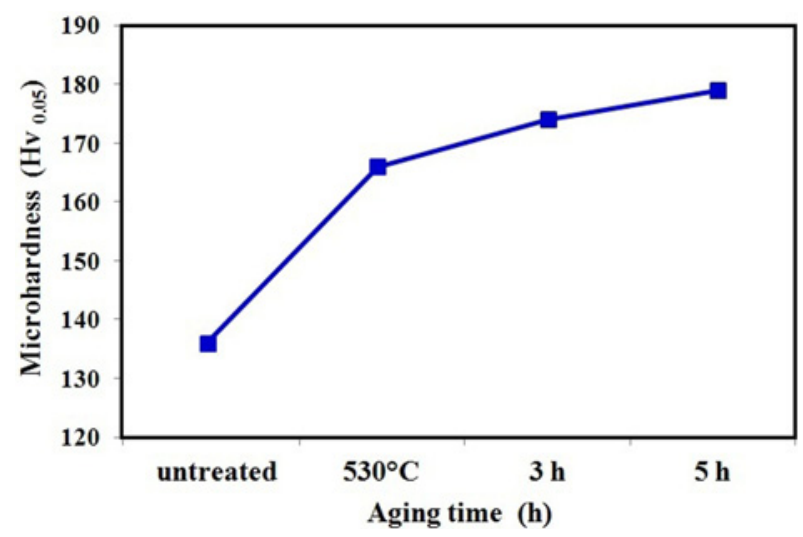

Fig. 6. Microhardness graph of the heat-treated aluminium alloy AA 2024.

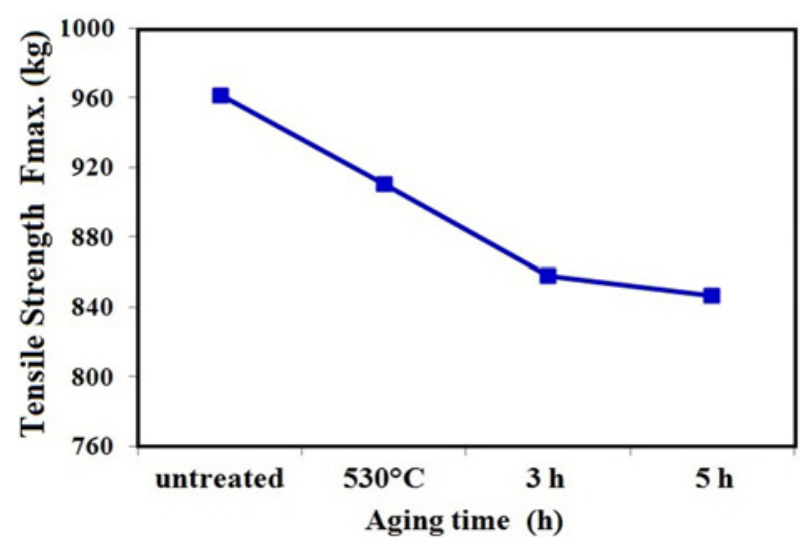

Fig. 7. Tensile test graph of the heat-treated aluminium alloy AA 2024.

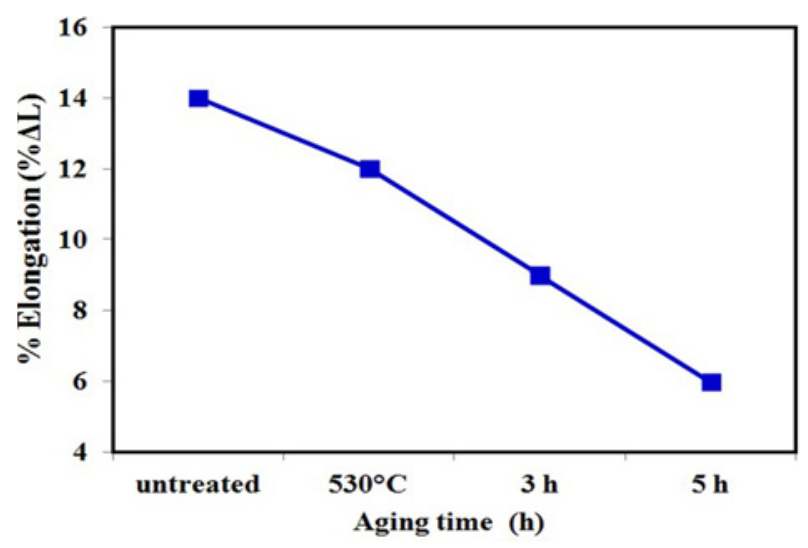

Fig. 8. \% Elongation $(\% \Delta L)$ graph of the heat-treated aluminium alloy AA 2024 as a result of tensile test analysis.

The increase in the values of these mechanical properties is due to $\mathrm{GP}(\mathrm{Cu}, \mathrm{Mg})$ zones and $\mathrm{Al}_{2} \mathrm{CuMg}$ phases and the homogeneous distribution of the small

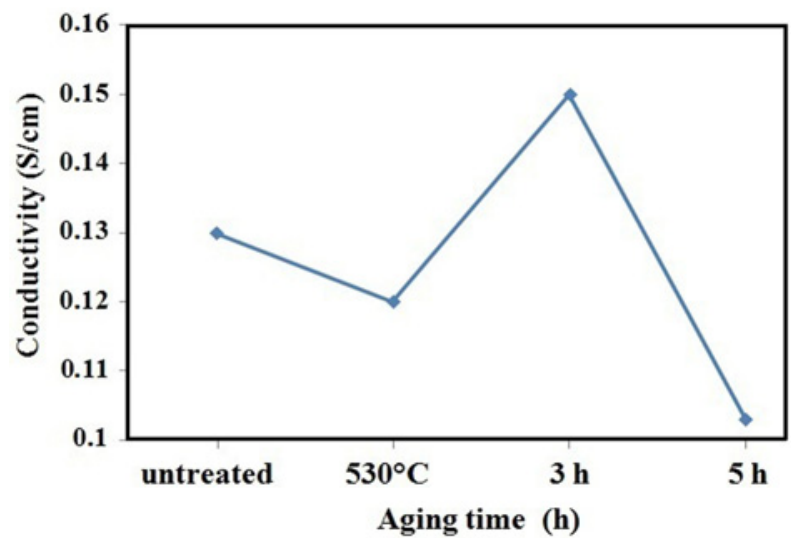

Fig. 9. Electrical properties graph of heat-treated aluminium alloy AA 2024.

particles in the internal structure after the heat treatment.

\subsection{Tensile test analysis}

Figure 7 shows the tensile test analysis graph of the samples of aluminium alloy AA 2024 artificially aged at $190^{\circ} \mathrm{C}$ in a conventional furnace environment. The fracture value $F_{\max }$ of the crude tensile test sample was calculated to be about $970 \mathrm{~kg} \mathrm{~mm}^{-2}$. It exhibited a ductile fracture characteristic due to $\mathrm{GP}(\mathrm{Cu}, \mathrm{Mg})$ zones and $\mathrm{Al}_{2} \mathrm{CuMg}$ phases thought to occur in the internal structure. The fracture value $F_{\max }$ of the aluminium alloy artificially aged at $190^{\circ} \mathrm{C}$ for $5 \mathrm{~h}$ was calculated to be about $840 \mathrm{~kg} \mathrm{~mm}^{-2}$. Due to $\mathrm{GP}(\mathrm{Cu}, \mathrm{Mg})$ zones and $\mathrm{Al}_{2} \mathrm{CuMg}$ phases present in the internal structure of the heat treated samples, the fracture values $F_{\max }$ were observed to decrease. Thus, the intermetallic phase can be considered to cause a brittle fracture.

In the optical microscope images of aluminium alloy AA 2024, $\mathrm{GP}(\mathrm{Cu}, \mathrm{Mg})$ zones and $\mathrm{Al}_{2} \mathrm{CuMg}$ phases increased depending on ageing time (Figs. 1-5). It was observed that $\mathrm{GP}(\mathrm{Cu}, \mathrm{Mg})$ zones and $\mathrm{Al}_{2} \mathrm{CuMg}$ phases formed in the samples after the heat treatment increased by maintaining their thermodynamic equilibrium positions. The fact that $\mathrm{GP}(\mathrm{Cu}, \mathrm{Mg})$ zones and $\mathrm{Al}_{2} \mathrm{CuMg}$ phases were harder than the matrix structure led the samples to exhibit a more brittle fracture characteristic. As can be seen in Fig. 8, the amount of elongation in the $L_{\text {final }}$ length varies depending on the ageing time, which means that as the ageing time increases, $L_{\text {final }}$ length decreases. This increased the brittle fracture characteristic of the heat-treated samples.

\subsection{Electrical properties analysis}

Figure 9 illustrates the graphs that show the dielectric properties of the samples of aluminium al- 


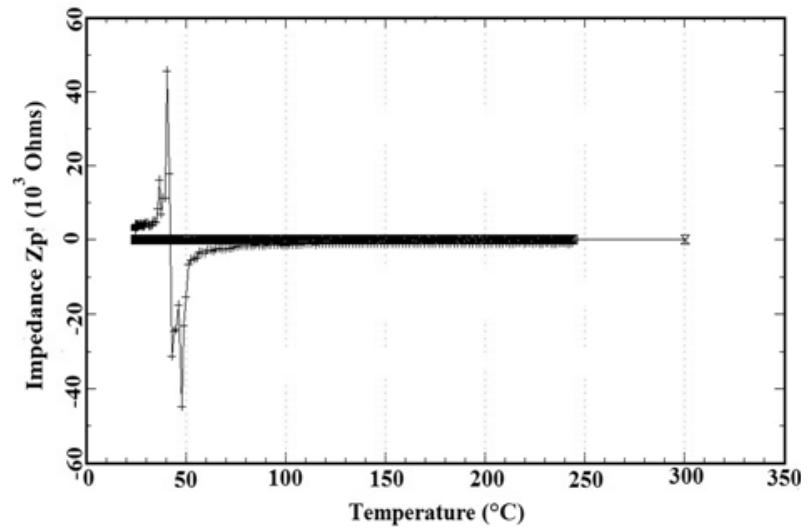

Fig. 10. Impedance temperature variation graph of untreated aluminium alloy AA 2024.

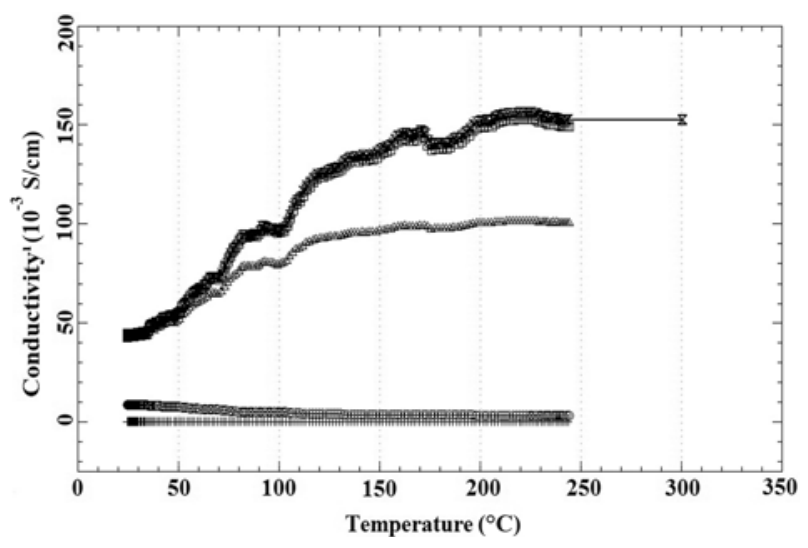

Fig. 11. Conductivity and electrical conductivity temperature change graph of untreated aluminium alloy AA 2024.

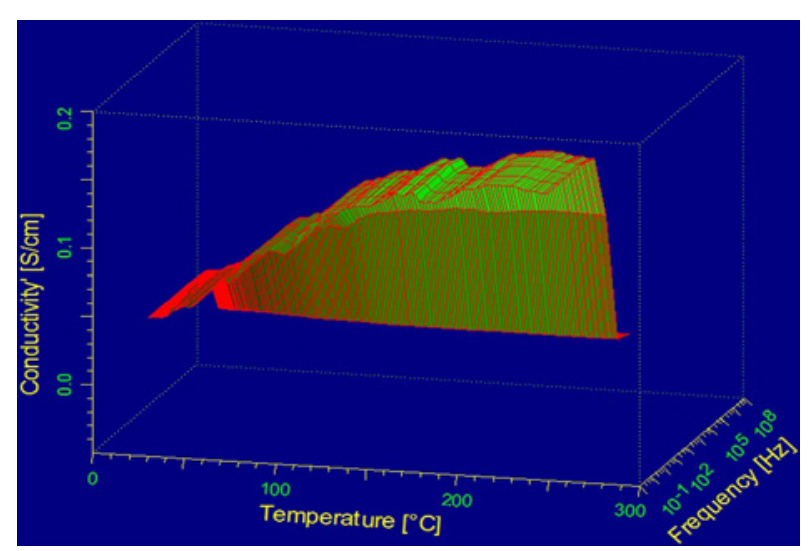

Fig. 12. Conductivity, frequency and temperature change graph of untreated aluminium alloy AA 2024.

loy AA 2024 artificially aged at $190^{\circ} \mathrm{C}$ for different periods of time in a conventional furnace environment. The conductivity value of the crude sample of the aluminium alloy at room temperature was about $0.13 \mathrm{~S} \mathrm{~cm}^{-1}$ while the electrical conductivity value of the sample quenched at $530^{\circ} \mathrm{C}$ at room temperature was about $0.12 \mathrm{~S} \mathrm{~cm}^{-1}$. This may be due to the increase in the $\mathrm{GP}(\mathrm{Cu}, \mathrm{Mg})$ zones, and the amount of $\mathrm{Al}_{2} \mathrm{CuMg}$ phases in the internal structure of the aluminium alloy system. The conductivity value of the sample artificially aged at $190^{\circ} \mathrm{C}$ for $3 \mathrm{~h}$ was found to be about $0.15 \mathrm{~S} \mathrm{~cm}^{-1}$ at $25^{\circ} \mathrm{C}$. Only the electrical conductivity value of the aluminium alloy sample artificially aged at $190^{\circ} \mathrm{C}$ for $5 \mathrm{~h}$ was measured to be about $0.10 \mathrm{~S} \mathrm{~cm}^{-1}$. The increase in the $\mathrm{GP}(\mathrm{Cu}, \mathrm{Mg})$ zones and the $\mathrm{Al}_{2} \mathrm{CuMg}$ phases in the internal structure of aluminium alloy AA 2024 at increasing artificial ageing times led to a fluctuation of the electrical conductivity value.

The impedance variation graph of aluminium alloy AA 2024 between $23-300^{\circ} \mathrm{C}$, is presented in Fig. 10 . According to this graph, it shows a very little increase up to $35^{\circ} \mathrm{C}$. At about $40^{\circ} \mathrm{C}$, it shows a sharp increase and goes up to $+40 \Omega$, declining up to $-40 \Omega$ at about $45^{\circ} \mathrm{C}$, showing a conductivity characteristic. However, no temperature-dependent impedance variation was observed between $70-300^{\circ} \mathrm{C}$. $\mathrm{GP}(\mathrm{Cu}, \mathrm{Mg})$ zones and the $\mathrm{Al}_{2} \mathrm{CuMg}$ phases in the internal structure of the aluminium alloy AA 2024 led the impedance value to remain constant.

Figure 11 shows that the change in the temperature had no effect on conductivity in the highest frequency $\left(10^{7} \mathrm{~Hz}\right)$. As the frequency decreased, its effect on conductivity increased. It was also observed that the effect of temperature on conductivity for 1 , 10,100 , and $1000 \mathrm{~Hz}$ frequencies remained at the same value. The conductivity was observed to increase depending on the increase in the temperature in the aforementioned frequencies. It can be argued that $\mathrm{GP}(\mathrm{Cu}, \mathrm{Mg})$ zones and the $\mathrm{Al}_{2} \mathrm{CuMg}$ phases in the internal structure of the aluminium alloy AA 2024 led the conductivity value to increase.

Three-dimensional graphs of temperature-dependent frequency and electrical conductivity of untreated aluminium alloy AA 2024 between $25-300{ }^{\circ} \mathrm{C}$ were obtained (Fig. 12). In Fig. 11, it was determined that the conductivity increased in low frequencies at low temperatures, while it decreased in high frequencies at high temperatures. It can be stated that the conductivity value of the aluminium alloy is inversely proportional to frequency and temperature because $\mathrm{GP}(\mathrm{Cu}, \mathrm{Mg})$ zones and $\mathrm{Al}_{2} \mathrm{CuMg}$ phases in the internal structure of the aluminium alloy AA 2024 were effective.

\section{Results and discussion}

In this study, the increase was observed in the intensities of $\mathrm{GP}(\mathrm{Cu}, \mathrm{Mg})$ zones and the $\mathrm{Al}_{2} \mathrm{CuMg}$ 
phases present in the internal structure of the samples of aluminium alloy AA 2024 system artificially aged in a conventional furnace environment.

EDS analysis indicated that $\operatorname{GP}(\mathrm{Cu}, \mathrm{Mg})$ zones and $\mathrm{Al}_{2} \mathrm{CuMg}$ phases, which occurred during the artificial ageing of the aluminium alloy used in the experimental study, precipitated (Figs. 1-5). Microhardness (Fig. 6) values were observed to increase due to the $\mathrm{GP}(\mathrm{Cu}, \mathrm{Mg})$ zones and $\mathrm{Al}_{2} \mathrm{CuMg}$ phases present in the internal structure of the sample of aluminium alloy AA 2024 quenched at $530^{\circ} \mathrm{C}$ and artificially aged at $190{ }^{\circ} \mathrm{C}$ for $3 \mathrm{~h}$. As can be seen in the curve, an increase in the microhardness was observed in the sample artificially aged at $190^{\circ} \mathrm{C}$ for $3 \mathrm{~h}$ in a conventional furnace environment after quenching. It can be stated that the $\mathrm{GP}(\mathrm{Cu}, \mathrm{Mg})$ zones and $\mathrm{Al}_{2} \mathrm{CuMg}$ phases present in the internal structure of the sample artificially aged for $3 \mathrm{~h}$ showed an increase in their thermodynamic equilibrium positions, which led to an increase in their mechanical properties values and a decrease in the conductivity.

In the tensile test (Fig. 7), a decrease was observed in the $F_{\max }$ fracture values of the heat-treated samples in the aluminium alloy AA 2024 system due to an increase in $\mathrm{GP}(\mathrm{Cu}, \mathrm{Mg})$ zones in the amount of $\mathrm{Al}_{2} \mathrm{CuMg}$ phases that occurred in the internal structure of the samples. It is thought that $\mathrm{GP}(\mathrm{Cu}, \mathrm{Mg})$ zones and $\mathrm{Al}_{2} \mathrm{CuMg}$ phases in the internal structure of the samples in the aluminium alloy AA 2024 system led to the brittle fracture. The fact that $\mathrm{GP}(\mathrm{Cu}, \mathrm{Mg})$ zones and $\mathrm{Al}_{2} \mathrm{CuMg}$ phases were harder than the matrix structure led the heat-treated samples to exhibit a more brittle fracture characteristic.

The scarcity of $\mathrm{GP}(\mathrm{Cu}, \mathrm{Mg})$ zones and $\mathrm{Al}_{2} \mathrm{CuMg}$ phases present in the internal structure of the crude sample in the untreated aluminium alloy AA 2024 system showed a ductile fracture characteristic, while a brittle fracture characteristic was observed with an increase in the $\mathrm{GP}(\mathrm{Cu}, \mathrm{Mg})$ zones and the $\mathrm{Al}_{2} \mathrm{CuMg}$ phases present in the internal structure of the sample, depending on artificial ageing times (Figs. 7, 8). Hence, according to the results of the tensile tests, as the artificial ageing of the aluminium alloy samples increased, the amount of percentual elongation was observed to decrease. In this way, it was determined that the brittle fracture characteristic of the heat-treated aluminium alloy samples increased.

$\mathrm{GP}(\mathrm{Cu}, \mathrm{Mg})$ zones and $\mathrm{Al}_{2} \mathrm{CuMg}$ phases, which constituted the internal structure of the crude aluminium alloy samples heated at low temperatures, and strong bond energies of the granule particles, increased the conductivity value. However, decreases were observed in the electrical conductivity of the aluminium alloy samples as the temperature was increased. This may be considered to be caused by the alloying elements with a low electrical conductivity coefficient, which is present in the alloy at high tempera- tures. Therefore, it decreased the electrical conductivity value of the aluminium alloy at increasing ageing temperatures. Although the crude sample used in the experimental studies had a better electrical conductor structure, it was observed to lose this characteristic with an increase in the temperature.

\section{Conclusions}

The results obtained can be summarised as follows:

- In the experimental study, $\operatorname{GP}(\mathrm{Cu}, \mathrm{Mg})$ zones and $\mathrm{Al}_{2} \mathrm{CuMg}$ phases were observed to occur as the artificial ageing time of the aluminium alloy AA 2024 system increased. These phases that occurred in the internal structure of the sample were observed to increase the microhardness values.

- In the aluminium alloy AA 2024 system, a decrease in the fracture values $F_{\max }$ in the tensile curve was observed due to the increase in $\mathrm{GP}(\mathrm{Cu}, \mathrm{Mg})$ zones and in the amount of $\mathrm{Al}_{2} \mathrm{CuMg}$ phases that occurred in the internal structure of the heat-treated samples. $\mathrm{GP}(\mathrm{Cu}, \mathrm{Mg})$ zones and $\mathrm{Al}_{2} \mathrm{CuMg}$ phases in the internal structure of the samples in the aluminium alloy system led to a brittle fracture. The fact that $\mathrm{GP}(\mathrm{Cu}, \mathrm{Mg})$ zones and $\mathrm{Al}_{2} \mathrm{CuMg}$ phases were harder than the matrix structure led the heat-treated samples to exhibit a more brittle fracture characteristic.

- $\mathrm{GP}(\mathrm{Cu}, \mathrm{Mg})$ zones and $\mathrm{Al}_{2} \mathrm{CuMg}$ phases that occurred as a result of the artificial ageing of aluminium alloy AA 2024 were observed to decrease the electrical conductivity.

- The highest electrical conductivity value of aluminium alloy AA 2024 was observed in the sample artificially aged at $190^{\circ} \mathrm{C}$ for $3 \mathrm{~h}$. This value was about $0.15 \mathrm{~S} \mathrm{~cm}^{-1}$.

\section{References}

[1] Maddox, S. J.: International Journal of Fatigue, 25, 2003, p. 1359. doi:10.1016/S0142-1123(03)00063-X

[2] Bargel, H. J., Schulze, G.: Werkstoffkunde (Material Science). Düsseldorf, VDI-Verlag Gmbh 1980.

[3] Wessel, J. K.: Handbook of Advanced Materials. Hoboken, John Wiley \& Sons, Inc. 2004.

[4] Marchezin, E., Pardini, L. C., Guimaraes, V. A.: Materia-Rio De Janeiro, 17, 2012, p. 889. doi:10.1590/S1517-70762012000100002

[5] Sik, A., Onder, M.: Kovove Mater., 50, 2012, p. 131.

[6] Lambot, H.: Mem. Acad. Ray. Belg., Classe Sci., 26, 1950, p. 1609.

[7] Styles, M. J., Hutchinson, C. R., Chen, Y., Deschamps, A.: Acta Materialia, 60, 2012, p. 6940. doi:10.1016/j.actamat.2012.08.044

[8] Perlitz, H., Westgren, A.: Arkiv Foer Kemi, Mineralogi Och Geologi B, 16, 1943, p. 1.

[9] Bischler, P. J. E., Martin, J. W.: In: AluminiumLithium Alloy-III. Eds.: Baker, C., Gregson, P. J., 
Harris, S. J., Peel, C. J. London, The Institute of Metals 1986 , p. 539 .

[10] Anand, M. S., Mararka, S. P., Agarwala, R. P.: J. Appl. Phys., 36, 1965, p. 3860. doi:10.1063/1.1713963

[11] Murphy, J. B.: Acta Met., 9, 1961, p. 563. doi:10.1016/0001-6160(61)90159-6

[12] Callister, W. D.: Material Science and Engineering. New York, Wiley 1990.

[13] Özerdem, M. S.: Journal of Materials Processing Technology, 208, 2008, p. 470. doi:10.1016/i.jmatprotec.2008.01.016

[14] Jiles, D.: Introduction to the Principles of Materials Evaluation. 1st Edition. Boca Raton, CRC Press 2008.

[15] Bencomo, A., Bisbal, R., Morales, R.: Materia-Rio De Janeiro, 13, 2008, p. 294. doi:10.1590/S1517-70762008000200007

[16] Aksöz, S., Ocak, Y., Maraşli, N., Çadirli, E., Kaya, H., Böyük, U.: Experimental Thermal and Fluid Science, 34, 2010, p. 1507.

doi:10.1016/j.expthermflusci.2010.07.015
[17] Ocak, Y., Aksöz, S., Marasli, N., Emin, C.: Fluid Phase Equilibria, 295, 2010, p. 60. doi:10.1016/j.fluid.2010.04.003

[18] Shakoor, A., Zhenggan, Z.: Journal of Materials Processing Technology, 211, 2011, p. 1736. doi:10.1016/j.jmatprotec.2011.05.011

[19] Zhi-Qiang, W., Yun-Bo, Z., Xian-Jun, R., Chao, W., Jiang, W., Zeng-Guang, Z., Wei-Li, R., Zhong-Ming, R.: Trans. Nonferrous Met. Soc. China, 22, 2012, p. 1106. doi:10.1016/S1003-6326(11)61290-9

[20] Muhammed, A. P., Saly, N. T.: Indian Journal of Chemical Technology, 20, 2013, p. 400.

[21] Karlík, M., Slámová, M., Mánik, T.: Kovove Mater., 47, 2009, p. 139

[22] Stulíková, I., Faults, J., Smola, B.: Kovove Mater., 45, 2007, p. 85. 